\title{
Better Comfort for Both Patient and Doctor: Prospective Randomized Study about Flexible and Rigid Cystoscopy
} Daha Iyi Hasta ve Doktor Konforu: Fleksibl ve Rijit Sistoskopinin Prospektif
Randomize Karşılaştırmalı Çalışması

Mehmet Remzi Erdem, Kemal Topaloğlu, Ömer Ergin Yücebaș, Feridun Șengör, Ahmet Rüknettin Aslan, Çağatay Tosun, Mehmet Akif Ramazanoğlu, Serdar Duvar

Haydarpaşa Numune Research and Training Hospital, Clinic of Urology, İstanbul, Turkey

What's known on the subject? and What does the study add?

This paper is the first study evaluating doctor comfort during cystoscopy.

\begin{abstract}
Objective

Cystoscopy is the gold standard method for the diagnosis and follow-up of non-muscle invasive bladder cancer (NMIBC). Since cystoscopy was performed under local anesthesia in office condition, patients' discomfort and pain during the procedure gained importance. Consequently, flexible cystoscopy (FC) has been used since 1970s to improve the patient comfort. In this study, we compared both flexible and rigid cystoscope in terms of patients and doctors comfort. Besides, we evaluated the effect of the type of cystoscopy for patients with benign prostatic hyperplasia (BPH).
\end{abstract}

\section{Materials and Methods}

We evaluated male patients with NMIBC. We excluded patients with urethral stricture, active hematuria and those who underwent diagnostic cystoscopy or first local cystoscopy for the first time. The patients were sequentially randomized to flexible (group 1) or rigid cystoscopy (group 2) groups. Pain, hematuria, disuria, and the postoperative necessity for medication were noted. In addition, doctor comfort during procedure was scored.

\section{Results}

When we compared both groups after the cystoscopy, patient and physician comfort in group 1 was statistically significantly superior to that in group $2(p<0.001)$. Besides, flexible cystoscopy provided better results in terms of postoperative hematuria, pain, and need of medication of patients. When we included only patients with $\mathrm{BPH}$, group 1 also provided better results.

\section{Conclusion}

Although flexible cystoscopy is costly, its higher comfort, and lesser postoperative morbidity may make it cost-effective, cumulatively. On the other hand, FC may also be favorable for older patients with BPH.

\section{Key Words}

Bladder cancer, cystoscopy, rigid, flexible, doctor comfort

\section{ÖZET}

Amaç

Kasa invazif olmayan mesane kanserlerinin tanı ve takibinde sistoskopi altın standarttır. Sistoskopinin ofis sartlarında, lokal anestezi altında gerçekleştiriliyor olması, hasta konforu ve ağrı durumunun önemini arttırmaktadır. Bu yüzden fleksibl sistoskopi hasta konforunu iyiliștirmesi nedeniyle 1970 'lerden beri uygulanmaktadır. Bu çalışmada fleksibl ve rijit sistoskopinin hasta ve doktor konforu açısından karşılaştırıldı. Ayrıca, benign prostat obstrüksiyonlu (BPO) hastalarda kullanılan sistoskopi tipinin hasta konforu üzerindeki etkilerini değerlendirdik.

\section{Gereç ve Yöntem}

Bu çalışmamıza kasa invazif olmayan mesane kanserli erkek hastalar değerlendirildi. Illk olarak uretra darlığı olan, aktif hematürili, olan ve ilk kez tanısal sistoskopi yapılan hastalar çalışma dışı bırakıldı. Hastalar fleksibl ve rijit sistoskopi olmak üzere sıralı randomize edilerek iki gruba ayrıldı. Hastaların ağrı, hematüri, disuria ve işlem sonrası ilaç kullanım gereksinimleri kaydedildi. Doktorların işlem sırasındaki konforları ayrıca not edildi.

\section{Bulgular}

Sistoskopi sonrası her iki grubu karşılaştırdığımızda, grup 1'deki (fleksibı) hastaların sonuçları hem doktor hem de hasta konforu açısından daha üstün olduğu ve istatistiksel olarak da anlamlı olduğu tesbit edildi $(p<0,001)$. Fleksibl sistoskopi, postoperative hematüri, ağrı ve işlem sonrası ilaç kullanım oranı açısından daha iyi sonuçlar sağlamaktadır. BPO'lu hastaları değerlendirmede de grup 1 daha olumlu sonuçlar sağlamıştır.

\section{Sonuç}

Fleksibl sistoskopun fiyatının yüksek olmasına rağmen, sağladığı yüksek komfor ve düşük işlem sonrası morbiditeler kümülatif olarak daha düşük maliyetlere sağlamaktadır. Ayrıca BPO'lu yaşı hastalarda fleksibl sistoskopi daha iyi bir görüntü sağlamaktadır.

Anahtar Kelimeler

Mesane kanseri, sistoskopi, rijit, fleksibl, doktor konforu

\section{Correspondence}

Mehmet Remzi Erdem MD, Haydarpaşa Numune Research and Training Hospital, Clinic of Urology, İstanbul, Turkey

E-mail: remzierdem@gmail.com Received: 22.03.2015 Accepted: 28.03.2015

Journal of Urological Surgery, published by Galenos Publishing. 


\section{Introduction}

Cystoscopy with local anesthetic, is the gold standard method for follow-up of non-muscle-invasive bladder cancer (NMIBC). Although cystoscopy with local anesthetic is not as comfortable as that under general anesthesia, it protects the patients from general anesthesiarelated morbidity. When we choose local anesthesia, we face pain and discomfort of the patient during the procedure. Therefore, the least painful and irritating way should be preferred for the follow-up of patients with NMIBC $(1,2,3)$.

Local anesthesia, listening to music and motivation as well as the type of cystoscopy are the manipulating parameters to improve patient comfort $(4,5,6,7)$.

Patient comfort and related factors during cystoscopy have been studied several times. However, the interaction between doctor and patient comfort has not been evaluated yet. In this study, we focused on physician and patient comfort, and its relationship with during flexible (FC) and rigid cystoscopy (RC).

Besides, cystoscopy may be more painful and complicated in male patients than in females because of longer urethra, urethral angulations as well as prostate enlargement in older male patients. We also evaluated the interaction between benign prostatic obstruction (BPO) and type of cystoscopy.

\section{Materials and Methods}

Our study was a randomized prospective clinical trial. Ethical approval was obtained from the Bezmialem Vakif University Ethics Committee, and all patients provided informed consent. Male patients, who underwent control cystoscopy due to NMIBC between April 2013 and October 2013, were included in the study. Patients who had previous urinary system pathology other than bladder cancer were excluded. Urinalysis was required for symptomatic patients, and prophylactic antibiotic was not recommended to any patient. All patients older than 50 years of age were evaluated for prostate diseases by prostate-specific antigen (PSA) test, digital rectal examination (DRE) and urinary ultrasound.

We included 386 patients with non-muscle-invasive bladder cancer (NMIBC), followed by cystoscopy under local anesthesia between April 2013 and October 2013. Female patients with NMIBC $(n=107)$, patients who underwent diagnostic cystoscopy for the first time $(n=39)$, patients unable to tolerate cystoscopy under local anesthesia $(n=5)$, patients unwilling to join the study $(n=45)$, and patients with persistent hematuria or disuria who could not be reached via telephone during the postoperative period $(n=86)$ were excluded. We included only 104 male patients without diabetes mellitus, coagulopathy, chronic renal failure, and other urinary system pathology. The number of patients, mean age and body mass index (BMI), and the number of patients with BPO in group 1 and group 2 were 55/49, 62.7 (3584)/66.9 (47-85), and 27.2/26.7, respectively (Table 1).

All patients were randomly assigned into two groups according to the type of cystoscope: FC (group $1 ; n=55$ ) or RC (group $2 ; n=49$ ). Patients with BPO in both groups were also classified according to their symptoms and ultrasounds to evaluate the effect of type of cystoscopy on patients comfort. All cystoscopy procedures were performed by the same urologist who had a five-year experience in endourology. A $15.5 \mathrm{~F}$ flexible or $17 \mathrm{~F}$ rigid cystoscope was used after skin preparation with polivinilpirolidon iodine $10 \%$, and intraurethral injection of $10 \mathrm{~mL}$ of $2 \%$ lignocaine gel. After 3 minutes of intraurethral local anesthetics, cystoscope was introduced from the urethral meatus via plain isotonic solution. Additionally, operation room staff prepared all patients in both groups for dorsal lithotomy. Urethral meatus, urethra, prostatic urethra, prostate, bladder and ureteral orifice were evaluated.

After completion of cystoscopy, the physician wrote operation note, scored his own comfort during the procedure and remarked disturbing factors during cystoscopy. At the same time, a nurse, who was blinded to the randomization of the patients, filled the patient's demographic values and pain score. The nurse asked the patient to score on a 10 $\mathrm{cm}$ visual analogue scale to report the severity of the pain felt during cystoscopy; 0 denoting no pain through to 10 denoting the worst. Statistical analysis was performed using SPSS 15.0 program (Chisquare, Mann-Whitney U test, unpaired t test, Fisher's exact test). A p value of less than 0.05 was considered statistically significant.

One week after cystoscopy, the patients were called and asked about seeing any blood in their urine, any discomfort during urination and any need to use antibiotic for a urinary problem in the past one week.

Additionally, the patients answered the question 'How was your comfort during the procedure? Good (0), Average (1), Bad (2) to reveal his comfort, and if his answer was 'Bad', we asked the following question to understand the reason: "What was the most important reason making it difficult?".

\section{Results}

\section{Patient and Doctor Comfort During Cystoscopy}

Patient comfort was evaluated via $10 \mathrm{~cm}$ VAS scale which was blindly administered by nurses. The mean VAS score in group 1 and 2 were $1.49 \pm 1.05(0-4)$ and $4.42 \pm 1.96(2-7)$, respectively. The differences in pain scores between patients was statistically significant (Table 2). In addition, operational comfort of the doctor was evaluated as goodmoderate-bad. The physician felt as good in 55 (100\%) patients in group 1, and in $25(51 \%)$ patients in group $2(p<0.001)$. The most important reason for uncomfortable cystoscopy was the patient irritation and pain $(n=24,87.5 \%)$.The other reasons, such as difficulty to watch extreme sides of the bladder, minimal bleeding when cystoscopy was blocked to take a better vision, and etc., were rarely seen.

\section{Comparison of Patients with Benign Prostatic Obstruction and Non-Benign Prostatic Obstruction}

Since older male patients had also BPO in addition to bladder tumor, we separately evaluated them to understand the effect of BPO on operational comfort. Pain in patients with BPO was highly seen in group $2(4.5 \pm 1.56(2-8))$ than in group $1(2.04 \pm 0.85(1-4))$ and it was statistically significant $(p=0.001)$. Besides, hematuria was mostly seen in group $2(p=0.004)$. Also, disuria and medication relieve symptoms after the procedure was mostly seen in group 2, but the differences were not statistically significant (Table 3 ). These complications mostly seen at $\mathrm{RC}$, because of enforcing cystoscopy in group 2, passing beyond enlarged prostatic urethra, causing damage to the urethral mucosa, increased inflammation, and fibrosis. However, the longterm result of the urethral damage was not evaluated in this study. 
Table 1. Demographic values of the patients (Unpaired T test, Chi-square, Man-Withney U, Fisher's exact test)

\begin{tabular}{|l|l|l|l|}
\hline Parameters & Group 1 $(n=55)$ & Group 2 $(n=49)$ & $p$ value \\
\hline Age & $62.7 \pm 10.03(35-84)$ & $66.9 \pm 9.64(47-85)$ & $0.034^{\ddagger}$ \\
\hline BMI & $27.2 \pm 2.99$ & $26.7 \pm 3.02$ & $0.37^{\sharp}$ \\
\hline $\begin{array}{l}\text { Tumor Stage } \\
(\mathrm{T} 1 / \text { Ta })\end{array}$ & $17 / 38 \alpha$ & $10 / 39 \alpha$ & 0.223 \\
\hline
\end{tabular}

BMI: Body mass index, $\alpha$ : first one is the number of pathological T1 tumor, second is the number of pathological Ta tumor $¥$ : ?

Table 2. Study results for comparison of both cystoscopy groups (Unpaired T test, Chi-square, Man-Withney U, Fisher's exact test)

\begin{tabular}{|l|l|l|l|}
\hline Parameters & Group 1 $(n=55)$ & Group 2 $(n=49)$ & $p$ values \\
\hline $\begin{array}{l}\text { Doctor comfort } \\
\text { good/tolerable/ } \\
\text { bad) }\end{array}$ & $0(55) / 1(0) / 2(0) \beta$ & $0(25) / 1(17) / 2(7) \beta$ & $<0.001$ \\
\hline VAS score & $1.49 \pm 1.05(0-4)$ & $4.42 \pm 1.96(2-7)$ & $<0.001$ \\
\hline Hematuria & 1 & 9 & 0.006 \\
\hline Disuria & 6 & 18 & 0.001 \\
\hline $\begin{array}{l}\text { Postoperative } \\
\text { medication }\end{array}$ & 2 & 6 & 0.02 \\
\hline B: Fistone & & 6 & \\
\hline
\end{tabular}

$\beta$ : First one is the number of better comfort during procedure, second is tolerable comfort during cystoscopy, last one is worse comfort during procedure.

Table 3. Comparison of both groups in patients with benign prostatic obstruction (Unpaired T test, Chi-square, Man-Withney U, Fisher's exact test)

\begin{tabular}{|l|l|l|l|}
\hline Parameters & Group 1 $(\mathrm{n}=24)$ & Group 2 $(\mathrm{n}=26)$ & $\mathrm{p}$ values \\
\hline VAS score & $2.04 \pm 0.85(1-4)$ & $4.5 \pm 1.56(2-8)$ & $<0.001$ \\
\hline $\begin{array}{l}\text { Duration of disuria } \\
\text { (day) }\end{array}$ & $0.45 \pm 1.14(0-4)$ & $0.79 \pm 1.14(0-4)$ & 0.102 \\
\hline Hematuria & 0 & 8 & $0.004^{ \pm}$ \\
\hline $\begin{array}{l}\text { Postoperative } \\
\text { medication }\end{array}$ & $1(12.5 \%)$ & $7(87.5 \%)$ & 0.05 \\
\hline $\pm ?$ & & & \\
\hline
\end{tabular}

\section{Hematuria, Disuria and Postoperative Antibiotic Usage}

One week after cystoscopy, the patients were called and asked about seeing any blood in their urine, discomfort during urination and need to use antibiotic for urinary problem throughout one week of cystoscopy. Hematuria, disuria and antibiotic necessity were seen in 1, 6, 2 patients in group 1 and 9, 18, 6 patients in group 2, respectively, and the differences were statistically significant (Table 2).

\section{Limitation of the Study}

Unfortunately, our RC (17 f) was slightly thicker than FC (15.5 f). Although we excluded patients with urethral stricture, RC might have irritated patients during angulation of the prostatic urethra. We perform cystoscopy with flexible and rigid, one by one, because we have only one flexible cystoscope and its sterilization lasts longer.

The patients in both groups were older than 60 years of age, thus, benign prostatic hyperplasia would be seen in both groups. However, group 2 patients were older than group 1 patients $(p=0.034)$, and the number of patients with BPO was also higher in group $2(p=0.337)$.

\section{Discussion}

Patient comfort during cystoscopy and the tolerability of $\mathrm{RC}$ and FC are the main points of several studies $(8,9,10)$. In addition, we evaluated patient comfort together with physician comfort. There has been no study to explain the relationship between patient and doctor comfort during cystoscopy. Our study revealed that, the more the patient comfort gets better, the more the doctor comfort concurrently improves during cystoscopy. When the patient feels comfortable, the physician can solely focus on the procedure and does not need to perform repeated look to see the same area, thus, the rate of overlooked neoplastic masses can be reduced. Consequently, providing better comfort for doctors and patients improve quality of procedure and reduce the risk of cystoscopy-related postoperative morbidity. In our study, postoperative short-term morbidity and need to medical help were rarely seen in group 1.

Although the equipment of $\mathrm{FC}$ is expensive, several articles have demonstrated that $\mathrm{FC}$ is superior to $\mathrm{RC}$ in terms of follow-up of NMIBC patients and is less painful during procedure $(10,11,12,13)$.

Our patients on NMIBC follow-up were mostly elderly. We preferred only male patients due to longer length of male urethra to exactly understand the effects of cystoscope. Older male patients with NMIBC were also candidates for benign prostatic hyperplasia and bladder outlet obstruction. For these patients, painless and comfortable cystoscopy is requested because of the challenging maneuver at the point of prostatic enlargement. Our study found that the best way of more comfortable and less morbid cystoscopy was FC.

Powell et al. have stated that FC had many advantages, such as performing with the patient in the supine position, under local anesthesia with ease (8). Tepeler et al. found similar results and reported that the discomfort score of operation room staff was significantly higher than that of RC arm due to the lithotomy position (14). However, we did not evaluate the level of comfort in operation room staff and positional differences in our study.

FC improved patient compliance and is tolerated better than $\mathrm{RC}(15)$. However, comparison of RC and FC was first reported in 1987 (16). Filling and emptying the bladder in FC is not as effective as in $R C$, especially in patients with hematuria or in those having blood clots in the bladder (9). In our study, we preferred patients without hematuria, admitted to cystoscopy control due to bladder cancer. Hematuria was seen in some patients undergoing RC postoperatively. On the other hand, patients undergoing FC did not have hematuria, during or after the procedure. Thus, we did not have any vision loss during FC.

Morbidity-related hospital admission, use of medicine and labour loss increase the cost of cystoscopy. We also found that postoperative mild hematuria and disuria were frequently seen in $\mathrm{RC}$ group. Repeated traumatic cystoscopy may trigger inflammation of the urethra and urethral fibrosis (17).

latrogenic infections are common and especially septic complication is frequently seen in patients with urinary tract infection (UTI). Although cystoscopy is minimally invasive, it may cause infection in up to $10 \%$ of patients. American Urological Association Best Practice 
statement recommends antibacterial prophylaxis before cystoscopy in patients at risk for UTI. Risk factors include advanced age, smoking, anatomic anomalies, steroid use, diminished immune function, and urethral catheters (18). A way of prevention of UTI is to protect the urethra and urinary system mucosa. When the mucosal integrity of the urethra is injured, asymptomatic bacteriuria reaches systemic circulation through the urinary tract. In our study, hematuria and disuria and postoperative antibiotic usage were more common in RC than in FC.

\section{Conclusion}

Not only patient comfort, but also the working conditions of the doctors are important in improving the quality of local cystoscopy. In our study, comfort of both patient and doctor was provided by FC. In addition, the position of the patient during the procedure, flexible structure of the instrument and its manageable optic make FC more comfortable than RC. When the cumulative cost of patient morbidity, success of the procedure and cost of the equipment are calculated for cystoscopy, FC may have advantages because of less morbidity, high success and patient-doctor compatibility.

\section{Acknowledgments}

We especially appreciate for OR staff for who are devoted themselves to our study.

Ethics Committee Approval: Bezmialem Vakıf University was approved by the Ethics Committee.

Informed Consent: Bezmialem Vakıf University ethics board has approved.

Concept: M. Remzi Erdem

Design: Kemal Topaloğlu

Data Collection or Processing: Ömer Ergin Yücebaş

Analysis or Interpretation: Feridun Şengör

Literature Search: Çağatay Tosun, M. Akif Ramazanoğlu, Serdar Duvar

Writing: M. Remzi Erdem, A. Rüknettin Aslan

Peer-review: Externally peer-reviewed.

Conflict of Interest: No conflict of interest was declared by the authors.

Financial Disclosure: Stationery costs of were funded by the authors.

\section{References}

1. Cicione A, Cantiello F, Damiano R. Cystoscopy in non-muscle-invasive bladder cancer: when and how (rigid or flexible). Urologia 2013;80 Suppl 21:11-15.
2. Canales BK, Gleason JM, Hicks N, Monga M. An independent analysis of flexible cystoscope repairs and cost. J Urol 2007;178:2098-2101.

3. Ciudin A, Diaconu MG, Gosalbez D, Peri L, Garcia-Cruz E, Franco A, Alcaraz A. Air cystoscopy is superior to water cystoscopy for the diagnosis of active hematuria. J Urol 2013;190:2097-2101.

4. Ho KJ, Thompson TJ, O'Brien A, Young MR, McCleane G. Lignocaine gel: does it cause urethral pain rather than prevent it? Eur Urol 2003;43:194196.

5. Patel $A R$, Jones JS, Babineau D. Lidocaine $2 \%$ gel versus plain lubricating gel for pain reduction during flexible cystoscopy: a meta-analysis of prospective, randomized, controlled trials. J Urol 2008;179:986-990.

6. Zhang ZS, Wang $X L, X u C L$, Zhang $C$, Cao Z, Xu WD, Wei RC, Sun YH. Music reduces panic: an initial study of listening to preferred music improves male patient discomfort and anxiety during flexible cystoscopy. J Endourol 2014;28:739-744.

7. Yeo JK, Cho DY, Oh MM, Park SS, Park MG. Listening to music during cystoscopy decreases anxiety, pain, and dissatisfaction in patients: a pilot randomized controlled trial. J Endourol 2013;27:459-462.

8. Powell PH, Manohar V, Ramsden PD, Hall RR. A flexible cystoscope. Br J Urol 1984;56:622-624.

9. Kennedy TJ, Preminger GM. Flexible cystoscopy. Urol Clin North Am 1988; 15:525528.

10. Flannigan GM, Gelister JS, Noble JG, Milroy EJ. Rigid versus flexible cystoscopy. A controlled trial of patient tolerance. Br J Urol 1988;62:537540.

11. Denholm SW, Conn IG, Newsam JE, Chisholm GD. Morbidity following cystoscopy: comparison of flexible and rigid techniques. $\mathrm{Br} J$ Urol 1990;66:152-154.

12. Gee JR, Waterman BJ, Jarrard DF, Hedican SP, Bruskewitz RC, Nakada SY. Flexible and rigid cystoscopy in women. JSLS 2009;13:135-138.

13. Quiroz LH, Shobeiri SA, Nihira MA, Brady J, Wild RA. Randomized trial comparing office flexible to rigid cystoscopy in women. Int Urogynecol J 2012;23:1625-1630.

14. Tepeler A, Silay MS, Akman T, Akcay M, Ersoz C, Kardas S, Erdem MR, Armagan A, Onol SY. Comparison of flexible and rigid cystoscopy-assisted ureteral catheter insertion before percutaneous nephrolithotomy: a prospective randomized trial. J Endourol 2013;27:722-726.

15. Snyder JA, Smith AD. Supine flexible cystoscopy. J Urol 1986;135:251252.

16. Figueroa TE, Thomas $R$, Moon TD. Taking the pain out of cystoscopy: a comparison of rigid with flexible instruments. J La State Med Soc 1987;139:26-28.

17. Joshua J. Meeks, Chris M. Gonzalez. Urethroplasty in Patients With Kidney and Pancreas Transplants. J Urol 2008;180:1417-1420.

18. Herr HW. The Risk of Urinary Tract Infection after Flexible Cystoscopy in Bladder Tumor Patients who did not receive Prophylactic Antibiotics. J Urol 2015;193:548-551. 